\title{
Teaching for Creativity and Informal Learning in Liminal Spaces
}

\author{
Terry Sefton \\ University of Windsor, Ontario, Canada
}

This paper discusses two projects that use practice as research to explore learning that takes place in liminal spaces-within the university but not formally in the classroom, while bridging discursive fields. In each project, university faculty participants and student participants in the fields of music, dance, and education, came together to collaborate on creating and performing new works. Participants worked with traditional techniques of composition in one project and storytelling and improvisation in the other. Both projects involved students and faculty working together on a voluntary basis. This paper documents how informal learning and creative thinking benefit from taking place in a liminal zone-within the university and its extended community, but not constrained by fixed discursive practices such as course expectations, assessment, or credit requirements-and allow for both students and faculty to learn from each other and to take creative risks.

Keywords: performance education, improvisation, informal learning, pedagogy of the arts

$\mathrm{I}$ $\mathrm{n}$ this paper, I will consider the discursive space that opens up when institutional and disciplinary boundaries are blurred, and when informal learning, or "less formal" learning, is allowed to take place in what are normally spaces of formal instruction. I will describe and discuss two different research and performance projects. In both projects I worked with collaborators, as fellow researchers and as co-creators and performers. In both undertakings, creative work was our central purpose; and the study of the effects of informal pedagogy on creativity was a secondary focus. I will begin by briefly discussing the institutional and political context in which the work took place.

A university is a highly structured environment, with an elaborate set of expectations and responsibilities for all who work and study there. Universities in Canada are funded in part with public money, and regulated by provincial gov-

(C) Terry Sefton. The content of this article is the sole responsibility of the author. The ACT Journal and the Mayday Group are not liable for any legal actions that may arise involving the article's content, including, but not limited to, copyright infringement. 
ernment legislation. Over the past decade, there has been increasing pressure in Ontario on universities to demonstrate "quality assurance"-using terminology more fitted to for-profit industry-to justify the public expenditure. In response to this ideologically driven agenda, educators have been urged to provide learning goals and success criteria for every course; students encouraged to measure academic progress as a consumption of credits; and universities compelled to produce "job ready" graduates for the workforce (Côté and Allahar 2011; Fullan 2013; Heap 2013). This shift towards a consumer (economic) model of education rather than a transformative one has consequences for the creative arts and for creative thinking (Finn 2015; Jones 2016). In a highly competitive environment focused on metrics of grades and graduation rates, it is difficult to "incentivize risk, failure, and valiant attempts that teach but go nowhere" (Finn 2015, 87). This can affect both how students approach learning and how teachers approach course planning, to avoid or minimize risk and to maximize success rates. As Pesch (2015) points out, "social contexts such as organizations and institutional domains apply certain ways to enforce the reproduction of rules" and one of these ways is through sanctions: "Discursive systems that are backed-up by sanctions provide a strong mechanism for the reproduction of rule-sets (384).

One potential avenue for teaching and learning that continues to pursue transformative rather than transactional goals is informal learning. Informal learning may take place in any number of ways and venues. Informal learning is most often defined by modality rather than content-how one learns rather than what one learns. The learner's motivation, and the means of communication, are often what characterize informal education, as well as the relationship between the learner and the "expert" or knowledge holder. Learning may begin as a solitary pursuit, by learning aurally or through imitation (e.g., from recordings or online video); it often moves on to learning that "takes place in groups and involves conscious peer direction and unconscious learning through peer observation, imitation, and talk" (Green 2005, 28).

According to Ruth Wright (2010):

Such learning has been described variously as non-formal or informal, drawing a distinction between this kind of learning and formal learning. Formal learning may be described as that which occurs in a traditional pedagogic environment where clarity of goals and procedures are clearly defined in advance and where learning results in certification or assessment. Non-formal learning occurs outside traditional learning environments, is not the result of deliberation and does not normally result in certification. (72) cism, and Theory for Music Education 17 (3): 79-100. doi:10.22176/act17.3.78 
Wright further clarifies that informal learning is "a deliberate attempt to be immersed in intense situations of non-formal learning, and therefore results in the creation of non-traditional social learning environments, combining interactive, non-linear and self-directed processes" (73). Most importantly, the "student" determines the process, not the "teacher." The role of teacher is determined through inter-relational negotiation:

Informal learning provides opportunities for the disruption of previously rationalised musical knowledges, allowing the equal/unequal relationship balance between teacher and student to be rebalanced and permitting students to create new discourse. (Wright 2014, 13)

As Green (2009) points out:

'Formal' and 'informal' ways of learning cannot usefully be conceived as mutually exclusive, or even as having clear boundaries between them. Nor is it always relevant to make distinctions between 'place' and 'type' of learning-for example, the idea that formal learning goes on in a school, and informal learning goes on outside a school, is too simple. (125)

The idea of place as merely a physical location is also "too simple." Place implies socially organized practices, associated with or required by ruling relations (Smith 1999). The projects in this study demonstrate some of the characteristics of both informal and formal learning. Some of the activities took place in a school setting, but not "in the classroom;" others took place outside of the university setting but still within the university community. In both the projects, teaching and learning occur and the roles of teacher and learner are fluid. The performance events and collaborative workshops do not carry the institutional regulatory and textual practices of formal learning: there is no course outline, no prescribed learning goals, no success criteria, no fees for students or salary for faculty; the activities are flexible and democratically decided upon; and participation is voluntary. The differences are differences of nuance, but, I will argue, of significance. Neither formal, nor informal, they might better be described as "less formal" education - like casual dress, an approach to teaching and learning that seeks to free itself from some of its more constrictive garb.

The creative, performance, and research projects I describe in this paper are: two series of music performance and composition workshops (the first project); and several dance and music improvisation open-studio performances and workshops (the second project). In both projects, the "expert" collaborator/creators and the "student" collaborator/creators worked together to develop and perform cism, and Theory for Music Education 17 (3): 79-100. doi:10.22176/act17.3.78 
each other's works. This is true to the creative process, which is "less linear than recursive" (Csíkszentmihályi 1996, 80). Performance was not the end goal, but rather, a stage in a cyclical process. Most significantly, workshops, rehearsals, critiques, and performances took place in a context that was outside of regular schooling-after hours, on weekends or post term-and in spaces that often used university facilities such as classrooms, performance and rehearsal halls, and dance studies, but that did not take on the typical social practices of the classroom, with students segregated from teaching faculty, or didactic presentations by teachers to students, or formal presentations of students for credit. I refer to this zone of activity as "liminal" because it does not fall clearly inside or outside of institutional practices. Liminal is also a theory or concept, that locates agency in an unstable position, possibly transitional.

Liminality is used differently, depending on discipline or field. It can refer to a concrete threshold between two areas, between the inner and the outer realm, an invocation of the gateway or portal that divides one from the other. In this architectural or spatial realm, it may also represent a metaphoric meaning, such as the "public square" or the "street" and those who inhabit it, as a type of politically situated discourse (Söderbäck 2017). It may denote a metaphoric domain or state that exists between or on the way to another domain or state, such as between the profane and the sacred (Willey 2016). It can represent an area of overlap between defined fields (Bourdieu 1994). It is used to describe thresholds of thought, such as between not knowing and knowing (Baillie, Bowden, and Meyer 2013), or the social position between two defined roles, such as student and teacher when that relationship becomes blurred (Cook-Sather and Alter 2011). In psychology, thresholds indicate a level of intelligence that may define the limits of certain capacities. It is used to conceptualize transitions or transformations or even revolutionary change. It can describe the mundane: "The liminal exists outside the everyday world, because liminal periods can take years (for example, postsecondary education)" or the extraordinary: "Liminal fields are temporary, erratic, and heterogeneous social spaces, which violently explode into existence at particular socio-historical junctures" (Willey 2016, 132). Liminal zones can exist as a transition between discursive fields. Discursive fields:

pertain to sets of meanings that actors have, and to the susceptibility of these sets of meanings to change. In turn, meanings relate to the explicitly and tacitly held ideas, beliefs, expectations, knowledge, and other cognitive schemes that are developed in a social context and that allow individuals to make sense of

Sefton, Terry. 2018. Teaching for creativity and informal learning in liminal spaces. Action, Criticism, and Theory for Music Education 17 (3): 79-100. doi:10.22176/act17.3.78 
empirical phenomena and that allow the coordination of social action. (Pesch 2016, 382)

The problem for the artist or performer is that such discursive fields are difficult to dislodge; these "tacitly held ideas" are often unconscious, and embedded in our sense of self. To stage an intervention that allows others to break out of the box, or to use individual agency to break oneself loose from these bonds, takes extraordinary effort.

During the workshops, artist residencies, and performances described below, liminality appeared in various of these forms. Spatially, most events took place in university facilities, but not as part of formal classes. In planning the activities, the performer-educator-researchers consciously chose to avoid, as much as was possible, the ordinary requirements and expectations of the institution in which they worked. Participants and researchers did not enter into the activities with set goals, but were searching for new knowledge or performances "at the edge of what is possible" (Broadhurst 2013, 12). Students and educators shared and switched roles and explored the discomfort that sometimes resulted (Cook-Sather and Alter 2011). Each of us opened ourselves to a state of risk, to "a fructile chaos, a fertile nothingness, a storehouse of possibilities, not by any means a random assemblage but a striving after new forms and structure" (Turner in Broadhurst 2013, 12). Liminality was a factor in physical/spatial, metaphoric, and discursive terms.

\section{Methodology}

This research falls within the field of arts-based research and uses the approach of "art practice as research" or "practice-led" research (Sullivan 2006; Bennett, Wright, and Blom 2009; Sefton and Bayley 2013). Each of these terms is slightly different. The projects discussed in this paper are best reflected in "art practice as research," which positions the art practitioner at the center of the research:

When art practice is theorized as research, it is argued that human understanding arises from a process of inquiry that involves creative action and critical reflection. The researcher and the researched are both changed by the process because creative and critical inquiry is a reflexive process. (Sullivan 2006, 28)

As performer-educator-researcher, I gathered data over the course of four different artist residencies in three different cities; and I continue to collaborate in creative performance projects that have grown out of these residencies. An artcism, and Theory for Music Education 17 (3): 79-100. doi:10.22176/act17.3.78 
ist residency is at once a site of data collection, of knowledge creation, and of dissemination through performance. The multiple residencies created linkages, threads that ran through each of them, which I will discuss later. Each residency illuminates the challenges of engaging students in creative work, and of producing creative work as a form of research. Video recordings were made of the teaching workshops, which allowed for a visual analysis of the interactions and discussions that took place.

\section{The Projects-Overview}

During the first project, university faculty members and undergraduate music performance students collaborated during a week-long composition and performance workshop. There were two of these residencies, one in 2014 and one in 2015, and they occurred at two Canadian universities in two different provinces, after the end of the academic term. Using pedagogies of engagement (Gallagher 2000) and critical creativity (Finn 2015), faculty members from departments of music and education worked together with students in non-hierarchal ensembles to rehearse, revise, and perform student and faculty compositions. Students who participated did so in order to develop their music compositions and have them performed, while working with professional musicians.

During the second project, two faculty members from different universities, in music education and dance education, developed a "new" approach to improvisation, using storytelling and mapping. During two artist residencies at two different universities, one in 2016 and one in 2017, faculty worked with each other, with other faculty musicians and storytellers, and with students of dance and education, to create improvisations based on personal stories of identity, and on visual depictions of place and memory (maps). Improvisations used a mixture of storytelling, dance, and music.

In each of these projects, the genesis was almost accidental, which may be important in its own way. The primary motivation in both cases was to work collaboratively on a creative endeavor, and the research component developed organically as we reached out to include students and colleagues. 


\section{First Project: Performance/Composition Workshops}

In 2014, I commissioned a new work from the Argentinian-Canadian composer, Martin Kutnowski. The composition was to be written for flexible instrumentation (treble instrument, bass instrument, keyboard) and in multi movement format as a suite, so depending on instruments and the preferences of the performers, the piece could be performed in parts or as a whole. As the commissioned work began to take shape, Martin, Jonathan Bayley, a flautist and academic colleague, and I were in contact, first through email, then by teleconferencing and videoconferencing, passing ideas back and forth. As all of us taught in university contexts, Martin in a Department of Fine Arts, Jonathan in a School of Music, and I in a Faculty of Education, our different pedagogical approaches within those different disciplinary and institutional frameworks became a subject of conversation.

Martin had already been working with his music composition students in organic and non-hierarchal ways, challenging himself to analyze occasional "failures" of pedagogy while teaching for creativity (Kutnowski 2015). We decided that, as we were currently in the process of developing this new composition, it would be interesting to work alongside students who were also in the process of composing new works. We wanted to see whether working alongside students, exposing our creative struggles to them, critiquing and workshopping each other's compositions, would create a learning environment for all.

We scheduled our first residency for the week following the end of winter term at St. Thomas University in New Brunswick. Martin recruited students to participate, as composers and as performers. Scheduling the workshops out of term was intentional, as we did not want the students to feel under any pressure to participate. Martin had taught a number of the students, so we wanted to mitigate the risk of conflict of interest. We hoped that the students would be motivated to have their compositions workshopped and performed by professional musicians; and to work alongside faculty but without the pressure of assessment or grades.

We set this up as a research project, with Research Ethics Board review. Students were informed of the research and were free to participate or not. Six students consented to participate. We three performer-educator-researchers, Martin on piano, Jonathan on flute, and I on cello, along with students playing a variety of instruments, rehearsed all the student scores, critiqued and made suggestions cism, and Theory for Music Education 17 (3): 79-100. doi:10.22176/act17.3.78 
for revisions, and came back each subsequent day to rehearse the revised scores, in an organic cycle of creation, revision, and refinement. At the end of the week, we put on a public performance of the student compositions, and of the first three movements of the newly commissioned work by Martin. The audience were invited to participate in the research, and were provided with a short exit survey after the concert and open discussion. We collected student reflections, video recorded the rehearsals, and kept reflective journals.

We had to continually remind ourselves of our goal of working in a nonhierarchical approach, as it was "natural" to fall back into a teacher-student model, to become didactic in the role of "expert;" and for student participants to look to us for leadership and decision-making. One of the strategies we used was to set the agenda for each day through discussion and consensus. Student participants had as much voice as faculty participants in determining the schedule, whose composition would be rehearsed, and who would take on various roles as conductor or performer. Over the course of the week, student participants gained confidence in taking on leadership, and on turning to each other for critique and advice.

The following year we carried out a similar composition workshop/artist residency at the University of Windsor in Ontario, where we recruited five students from the School of Music and the Faculty of Education. Two other performance faculty, a pianist and a vocalist, joined us during several days of workshopping student compositions. We also rehearsed Martin's commissioned composition; by this time, he had added two more movements. At the end of the week, we gave a public performance of all of the compositions.

Video data from both workshops was viewed by the researchers (Martin Kutnowski, Jonathan Bayley, and I), and analyzed for evidence of who spoke, who initiated or directed activity, how players communicated while performing (gesture, body language), peer-to-peer learning, faculty-to-student mentoring, and group discussions. The students were asked to complete brief reflections, responding to a short questionnaire at the end of the week. Viewing the video of the rehearsals, it was striking how often students spoke and led discussions. Also visible was how students increasingly turned to peers rather than faculty participants, to give and receive advice. This was not something that we (musicianeducator-researchers) had noticed in the moment, as we were busy checking scores, practicing, or talking to each other. The substance of what students and faculty said differed: faculty members often asked students to verbalize what they cism, and Theory for Music Education 17 (3): 79-100. doi:10.22176/act17.3.78 
were striving for; to clarify their artistic goals and find aesthetic or technical solutions. Faculty members also provided concrete suggestions for performance practice and normative notation. Students might verbalize what they were trying to achieve in metaphoric or descriptive language ("it should be powerful"), but could not always find a practical way of notating it on the page, or of signaling musicians to produce the effect they desired. As we rehearsed we would stop and discuss, and each of us, whether currently performing or sitting in the audience, would offer critique. As one student described it:

I'm so thankful to all of you for helping and having professionals look at it and telling me exactly what needs to be done and stuff ... because when we did my piece in my new music class, it was just ... the choir was trying to learn the notes and that was it ... and all they told me was that it was too hard and they can't sing it ... so ... that wasn't helpful.

The number of participants was small-only 11 students and five faculty across both projects, plus "drop-in" faculty and students who came to observe. While the numbers were limited, the data collected was extensive which allowed for "thick description" (Geertz 1973) and reliability, including the words and gestures, the "practical consciousness" of all of the "social actors" (Hamel 1997).

Most of the students cited "group discussion" as the primary mode of learning during the workshops; peer-to-peer, and one-on-one with faculty being the other favored modes. We coded the videos based on three overarching domains: Technical, Social, and Aesthetic. Each of these was not discrete; in some cases, we identified themes that might be included in all three, such as performerconductor interaction. Each of the faculty participants kept notes and wrote reflections. We were all struck by the intensity-how focused students were, how focused faculty were, and the "seriousness" of the working atmosphere. As one faculty participant recalled:

I think that we showed them [student participants] not just that they could write music, but also that they could go from feeling insecure and tentative to feeling empowered and assertive. This confidence was generated, in the emotional realm, by the relaxed and risk-free atmosphere, paired, in the technical realm, by the many practical suggestions.

The "risk-free" atmosphere was perhaps not a feeling shared by all or all the time. However, students were able to overcome their sense of risk, in that they were willing to submit their work to criticism and to come back each day with revisions, ready to submit again to live performance and critique. The formal aspect of the workshops, in particular the critique and revision process, is very similar to cism, and Theory for Music Education 17 (3): 79-100. doi:10.22176/act17.3.78 
a master class in the tradition of music academy or art school. The informal aspect was the non-hierarchal (not always achieved, but intended) relationship between all collaborators, peer learning, and voluntary participation, while working within an institutional frame (place and habitus).

\section{Second Project: Dance and Music Improvisation}

The second research project came about while I was visiting another university in Canada, and stopped in to look at the university visual arts gallery. There I ran into the artist of the exhibition that had just been installed, Kathryn Ricketts, dancer and professor of dance education. We fell into conversation about her work, which combines narrative, found objects, collaboration with musicians and storytellers, and improvised dance. The conversations that arose from that chance meeting led to us working together in a very exploratory way a few months later when I returned to the city. We started working by ourselves in her dance studio, improvising dance and cello. I had very limited experience with music improvising, so this was a challenge to me. We began in very rudimentary ways, setting a time limit for our improvisations, such as two minutes; and using words of descriptive characteristics written on the chalk board ("cause and effect"; "tone, rhythm") to provide a prompt to our improvisations. We told each other stories-as one does when getting to know a new acquaintance-and those stories were often situated by place; where something happened, descriptions of settings. Noticing how often we referred to symbolic places we remembered (idea of home-childhood; first shared apartment-adulthood; "wild wood"-adventure); and to actual geographic locations, we began to work with maps. These were actual geographic maps of cities or neighborhoods; as well as personal maps, pictures that we drew to depict where stories took place (figure 1). These maps, or representations of place in the remembered past, provided another form of prompt for our improvisations. We coined a term for this process: "cartoelicitation." It quickly became evident to both of us that the work we were embarking on was a form of practice as research, using "creative action and critical reflection" (Sullivan 2006, 28). We were interested in where it might lead, for both our performance and for our pedagogical practices.

Kathryn invited her undergraduate dance education students, as well as professional dancers, to come and work with us. We continued to develop the idea of carto-elicitation with them. We provided large rolls of paper and felt drawing cism, and Theory for Music Education 17 (3): 79-100. doi:10.22176/act17.3.78 
pens, and students positioned themselves around the room, on the floor, drawing visual representations as an answer to the question "where are you from?" Kathryn and I asked students to talk about these images, if they wanted to, and these verbal narratives created another level of story to add to the visual "map." Only a couple of students initially did not want to talk about their images; but as stories were told, and improvisations took place, even those two volunteered to speak. The stories were stories not just of place, but of identity; of family; of personal conflict; or relationships. Kathryn and I would improvise dance and music that embodied their stories, or we would have them create improvisations that responded to the maps of others. The activities were initially faculty directed, but the improvisations were co-created, and the students quickly took over the creative direction. This sometimes pushed me into uncomfortable territory in my performance practice. During one improvisation, a student, moving from behind, crawled beneath and through the legs of the chair on which I was sitting, while I was playing cello. This was the first time, but not the last, while improvising with dancers, that I had to find a much higher tolerance for physical proximity and for personal risk. I had to switch between roles, as a performer, as a research collaborator, as an educator, or as a learner. As a performer, I would not normally have "allowed" my physical boundaries and the safety of my music instrument to be invaded to that extent. I often felt I was "not doing it right" when I was improvising, or that I did not feel free to initiate changes of creative direction. When I was performing, it was difficult to observe what others were doing, so I would reposition my chair, to be able to watch dancers reflected in the dance studio mirrors. When I was listening to students' stories, and encouraging their active participation, I was in my "teacher" role. The pay-off for participants was that they could learn, as I was learning, from all stages of the activities. There was no externally defined goal for them, so motivation of the participants, to attend the workshops, to engage in different activities or performances, was personal and not something they needed to, or were asked to, make public. These workshops took place at the University of Regina in the fall of 2016, and over 30 dancers and dance students took part.

In the spring of 2017, Kathryn arrived at the University of Windsor for a fourday artist residency. We held open "studio" times when faculty and students could come and observe us at work; and Kathryn led workshops for students on how to use "embodied" narrative work, combining movement and storytelling. The number who participated in these various events ranged from a handful of cism, and Theory for Music Education 17 (3): 79-100. doi:10.22176/act17.3.78 
dancers and colleagues observing in an open studio, to groups of fifteen to twenty undergraduates or graduate students for workshops. None of the work we did with students was required-these were voluntary events, and students opted to attend in their own time. Throughout these artist residencies, Kathryn and I continued to explore our creative collaboration, and to develop an intuitive depth to our co-improvisation. I was learning from Kathryn and from self-directed exploration, as we worked without scripts or scores, using audio visual cues and prompts, and imitative strategies. I also performed at two public events in Kathryn's city, improvising on cello with dancers and with a storyteller. These performance events took place off-campus in a performance space. As an outgrowth of the workshops and residencies, Kathryn and I began to work on a piece that would integrate all of the elements that we had been exploring: adapting other people's stories, telling our own stories, mapping stories, creating music and dance improvisation as a way of interacting with story, and video recording. The culmination of this work was a video/performance art installation with live performances of carto-elicitations, which we submitted to a juried show at the Art Gallery of Windsor. It was accepted and included in the 2017 Triennial of Contemporary Art, that ran from October 2017 to January 2018. We wrote an essay for the exhibition catalogue, about our creative and learning process, and the concept of carto-elicitation (Sefton and Ricketts 2018).

\section{Discussion}

Each of these projects documents how pedagogical engagement takes on a different shape outside of the formal requirements of institutional learning, such as setting learning goals, evaluating student work, and maintaining teacher/student roles. This positioning of the work serves to subvert the politics and constraints that are imposed by institutional expectations, and to encourage autonomy of the subject within a network of creative collaboration and voluntary dependence (Kanellopoulos 2012). This was particularly evident in the improvised dance workshops, where the "students" truly took over the creative process, creating their own maps and improvisations, while collaborating with me as cellist, or with other student dancers or storytellers. This may reflect the greater freedom students felt in improvisation, where classical or technical dance skills are less rigorously imposed or expected. The roles of teacher and student were more entrenched during the composition workshops. Although student participants took

Sefton, Terry. 2018. Teaching for creativity and informal learning in liminal spaces. Action, Criticism, and Theory for Music Education 17 (3): 79-100. doi:10.22176/act17.3.78 
on various tasks-as conductor, as critic, as performer, as composer-the flow of information, feedback, and expertise was still largely (though not exclusively) from faculty participants to student participants. The repositioning and reidentifying of the teacher as a collaborator, a co-creator, and a co-learner, partially upset the inherent power dynamic of teacher/student. But this was not enough to erase the differential of expert to learner. However, over the course of the workshops, students took on greater autonomy and responsibility for their own learning. In written reflections, student participants described what they had learned:

You must be specific and decisive in knowing your piece and what you want from the performers. I also learned that collaboration can inspire new ways of thinking that were perhaps intuitive, but the ability and knowledge to express it hadn't been formed yet.

Getting to discuss and collaborate one-on-one with the performers. It really helps to put the music into perspective and allow the creative process to flow and even open new doors and perhaps challenge it.

How performances were crafted from the minimal "structures"- also the speed at which interpretations of the music were worked out.

That I shouldn't be afraid to try "risky" thing such as sight-reading and improvisation.

Not as chaotic as it first appears.

Sometimes the gap between faculty and students was too great, and the illusion of equal collaboration became visible. A different student wrote:

Sometimes they [faculty] were so academic that I found it hard to voice my immediate concerns about performing a score to them.

The institutional context is an added axis of effect. The dance workshops in Regina took place in the university dance studio, although on the weekends and outside of class time. During the workshops, the relationship/roles of teacher/student were still clearly defined, even though the workshops took place on a voluntary and extra-curricular basis. The dance workshops that took place in Windsor happened in a gym and a drama studio, not the normal venues for the students or faculty colleagues who attended. Just by shifting to another, less familiar, site within the university, the activity took on a freer, less classroom-like ambiance. Other faculty members dropped in to observe and, in some cases, participate, in the improvisations and in the discussions. This displacement from the classroom, or from the "traditional learning environments" (Green 2005) contincism, and Theory for Music Education 17 (3): 79-100. doi:10.22176/act17.3.78 
ued when Kathryn and I exhibited and performed our work in the Art Gallery of Windsor. During our public performances there, we interacted with spectators, elicited their stories, and created impromptu performances of their stories.

Howard Becker (1982) describes the complexity of Art Worlds, with their multiple players-artists, critics, dealers, suppliers, collectors-whose roles intermesh in a skein of social practices. Bourdieu (1994) described this social phenomenon as a "field of cultural production." Within that field he identified a subfield, the "field of restricted production" (115). This refers to production of cultural works or products for the consumption by other producers of cultural productions, not by the general public. The motivation is different than in the production of cultural works for, in Bourdieu's words, the "non-producers of cultural goods," or for the "non-intellectual fractions of the dominant class" (115). Furthermore, Bourdieu referred to "isolation and separation," which contribute to the "autonomy" of the cultural producer. In each of the workshops and residencies, roles and sites and domains were not fixed; roles shifted, or participants occupied different status at different times. The changes of venues, from classroom to studio to art gallery, heightened the possibilities for different relationships and interactions, and for communication and learning that flowed in nonlinear and unpredictable ways. The immediate audience for our performances, both of the music compositions and of the dance improvisations, was each other, so we were operating, in Bourdieu's terminology, in a "field of restricted production." The "autonomy" of each of the participants was respected, as each participant created work that was personal to them; and the significance of or the meaning of each performance or story remained separate from each other or from the whole.

During both the music composition and the dance improvisation projects, students took on leadership and agency when their compositions or improvisations were being rehearsed and performed; a university classroom became a performance venue; a faculty member became a member of the "band"; students took on the role of organizing rehearsal schedules, or of critiquing performances, or of documentation (video recording and photography were done by faculty and by student participants). Dance students improvised performances for each other, and impromptu public performances took place at events attended by members of the university arts community. The benefits of working in this flexible and informal way was identified by student participants in their written reflections:

Sefton, Terry. 2018. Teaching for creativity and informal learning in liminal spaces. Action, Criticism, and Theory for Music Education 17 (3): 79-100. doi:10.22176/act17.3.78 
I love this kind of work and collaboration and I hope to get this chance again in the future because I believe that when you surround yourself with such a diversity of skills and knowledge, you gain so much more intelligence because you're learning from multiple minds.

And

[I] felt it was wonderful environment to feed off everyone's energy and grow.

A faculty participant provided a similar description in their research notes:

It is a discussion, more like a conversation around a dinner table - family members sharing commonality, together for the same purpose (performing a piece). The ideas are more dispersed (from different people; sudden injection of new idea)-not chaotic or hectic, but a multiplicity of ideas that get thrown out at the same time.

The lack of formal structure was only partial. The workshops were organized, in the sense that rooms were booked; and equipment such as instruments, music stands, and lights, and rolls of paper and drawing pens for mapping, were supplied. As faculty members and research collaborators, we discussed and planned the general outline of the workshops, and set the wheels in motion, so to speak. However, the students felt free to attend when they could, and to participate at their own level of readiness.

The work that students and faculty undertook in each of these workshops and residencies was not without intentionality and goals. But these goals were selfdetermined, and the incentive to participate was based on internal motivation, and not on extrinsic factors such as credits or grades. Faculty participants and researchers were also operating from individual and internal motivations. In each of the residencies faculty members were working with each other to create and perform new works. Students were able to observe faculty performers as we rehearsed, working through and rejecting unsuccessful ideas, as well as revising and refining successful ideas, whether dance and music improvisations, or a commissioned piece of music. In other words, students got to see faculty members, professional creators and performers, taking risks and occasionally failing.

\section{Conclusions and Implications}

The idea of the university (Newman 1852) has changed radically from the time of Cardinal Newman, who argued for education as an end in itself, and as a vehicle for developing the "beauty ... of the intellect." Contemporary critics have had cism, and Theory for Music Education 17 (3): 79-100. doi:10.22176/act17.3.78 
much to say about Newman's idea, and the inherent elitism of its "classsegregated division of knowledge" (Jones 2016, 62). Contemporary trends in public education have espoused a more utilitarian than aesthetic ideology, even when superficially supportive of the arts. As previously noted, the Ontario government, through the Ministry of Education, has demanded increasing demonstrations of "accountability" from universities, and this has led to normalizing practices in the classroom, such as standardized course outlines, defined learning outcomes or objectives, and assessment criteria for every student activity. This approach has benefited some fields, those that depend on critical thinking and measurable skill acquisition, more than others, those that require creative thinking and risk taking (Finn 2015). Music performance requires measurable skill acquisition, but it also requires something more: interpretation, style, originality, a unique "voice" or sound, personal charisma. Performance requires something that is very hard to measure-in a word, artistry. As Gallagher (2000) points out:

A word like objective is not a neutral word but an ideologically loaded one. It implies a kind of functionalism in education that is often at odds with the more unpredictable nature of outcomes in the arts. (121)

The movement of current pedagogical practices is to anticipate and then measure learning "outcomes" as a signal of both the success of the student, the success of the teacher, and the success of the institution. Michael Fullan, who has served as advisor to the Ontario government, promotes a structured and measured approach to teaching and learning with an emphasis on accountability. One of the priorities Fullan (2013) identified for the government is "developing provincial measures of progress and reporting publicly on them" (11). He referred to "concrete exit outcomes" as providing the ideal measure of student and also school success (10). This form of accounting reduces the process of education to a transactional and contractual event. Intention and assessment are not, necessarily, damaging or impossible in the arts; but evaluation must take into account the characteristics of uncertainty and risk of creative work, the highly individual nature of creative process, and the often invisible mental preparation that precedes creative performance (Gallagher 2000; Elkins 2001). The pressure to create a certain number of works of art during a Studio Fine Arts degree program, or to prepare a certain number of recitals during a Performance Music degree program, can work against depth and originality. Furthermore, evaluation of a percism, and Theory for Music Education 17 (3): 79-100. doi:10.22176/act17.3.78 
formance or art work, measured against some imaginary standard of excellence, assumes there is a commonly agreed upon standard of comparison.

The students who participated in the composition and dance workshops, whether they were performance students, general arts students, dance students, or education students, all engaged actively in acts of the "social imaginary" (Taylor 2004). Taylor coined this phrase to identify the ways in which "ordinary people 'imagine' their social surroundings, and this is often not expressed in theoretical terms, but carried in images, stories, and legends" (Taylor 2004, 23). The willingness of students to take these risks was at least in some part, I would suggest, due to the liminal condition, the neither-this-nor-that of the workshops and residencies. The participants were invited to engage but under no constraint to achieve any defined goal. Each of us entered into these events and activities with our own motivations, and perhaps, our own goals, but internally defined. At the same time, the institutional setting was familiar to all, and lent its own form of comfort, of familiarity, and sense of belonging.

An artist may set herself a problem, but solving it is not necessarily the outcome. Rather, art emerges out of the struggle, and may still remain, even in its supposedly finished state, partially inchoate, or forever open to revision (Barthes 1975; Elkins 2001). While student composers had their works performed at a public concert at the end of the week, the performances took the form of provisional statements; the instrumentation was often not what was intended, but necessitated by the performers available; and the stage of development was in most cases not "finished" but still in a state of development. The dance improvisations were mostly performed for each other, and not as some final product or evidence of progress or learning outcome; the improvised performances at the more formal "Loft" events were impromptu, as dancers who had participated in our open studios took the floor to add to the evenings planned performances. The value of working in undefined ways and in liminal spaces-temporal, physical, and regulatory; an absence, or near absence, of an end goal or of evaluation; fluid roles and responsibilities-seemed to encourage participation and engagement (Gallagher 2000), and to further the process of creation.

The positive response of participants in the open studios, workshops, and artist residencies point to the benefits of learning that happens in the nonclassroom, and in the liminal spaces that exist between defined institutional contexts. The projects reflected many of the attributes of informal learning. Activities took place "outside traditional learning environments" or repurposed traditional cism, and Theory for Music Education 17 (3): 79-100. doi:10.22176/act17.3.78 
learning environments; and did not lead to "certification" (Wright 2010, 72). Furthermore, the relationship between learners and "experts" was organic, as roles changed frequently, unbalancing the "equal/unequal relationship between teacher and student" (Wright 2014, 13). There was peer-to-peer learning in every environment, not only between student participants, but also between faculty, who were also developing and extending their own knowledge and competencies, whether in performance or in the skills of improvisation. Much of the learning was done aurally or through imitation, in non-linear and self-directed ways (Green 2005; Wright 2014). At the same time, we took advantage of the "traditional" site of the university; facilities such as dance studios, recording technology, and the proximity of faculty and students who could simply drop in and participate without pre-registering or planning, added to the richness of the interactions and the dialogue. The activities that took place "off" site, in performance venues or at the art gallery, still benefited from the extended community of university colleagues and students, as participants, spectators, and contributors. Hence, the concept of liminal space, of learning and creative activity that partakes of both formal and informal attributes, both within and outside the "traditional" sites of learning. As a final observation, the students and faculty engaged fully in a "deliberate attempt to be immersed in intense situations of nonformal learning” (Wright 2010, 73).

Faculty participated without compensation, and with some trepidation about whether students would participate and whether it would be creatively productive. This uncertainty created, in itself, a charged state, an open current. At times faculty participants found it difficult to let go of the usual structural certainties of course planning or even of rehearsal schedules. I never became comfortable not knowing what would happen each day, who else would be there, or what would be possible on a given day. That discomfort forced me to shift out of my habitual modes of interaction, to let go of my own expectations for control or for concrete outcomes, and to spend time in a liminal state of unknowing.

I return to a powerful memory in my own narrative when, as a teenager, I attended Banff School of Fine Arts. Over several summers, I learned not just from the visiting artists who led masterclasses or tutored us one-on-one; but I learned from my fellow students, from the days spent hanging out in the painting studios, the dance studios and the rehearsal halls, and from wandering in the forests and hiking the canyons. I experienced time outside of time, "time reserved for luxurious consumption and excess" (Bataille in Willey, 2016, 131). The projects de-

Sefton, Terry. 2018. Teaching for creativity and informal learning in liminal spaces. Action, Criticism, and Theory for Music Education 17 (3): 79-100. doi:10.22176/act17.3.78 
scribed in this paper served to remind me of what can happen in the liminal space that exists between formal schooling and the domain of cultural production, when discursive spaces, which are normally organized by institutional relations of ruling, are uprooted or at least unsettled, creating openings for something wilder to emerge, a field of new possibilities.

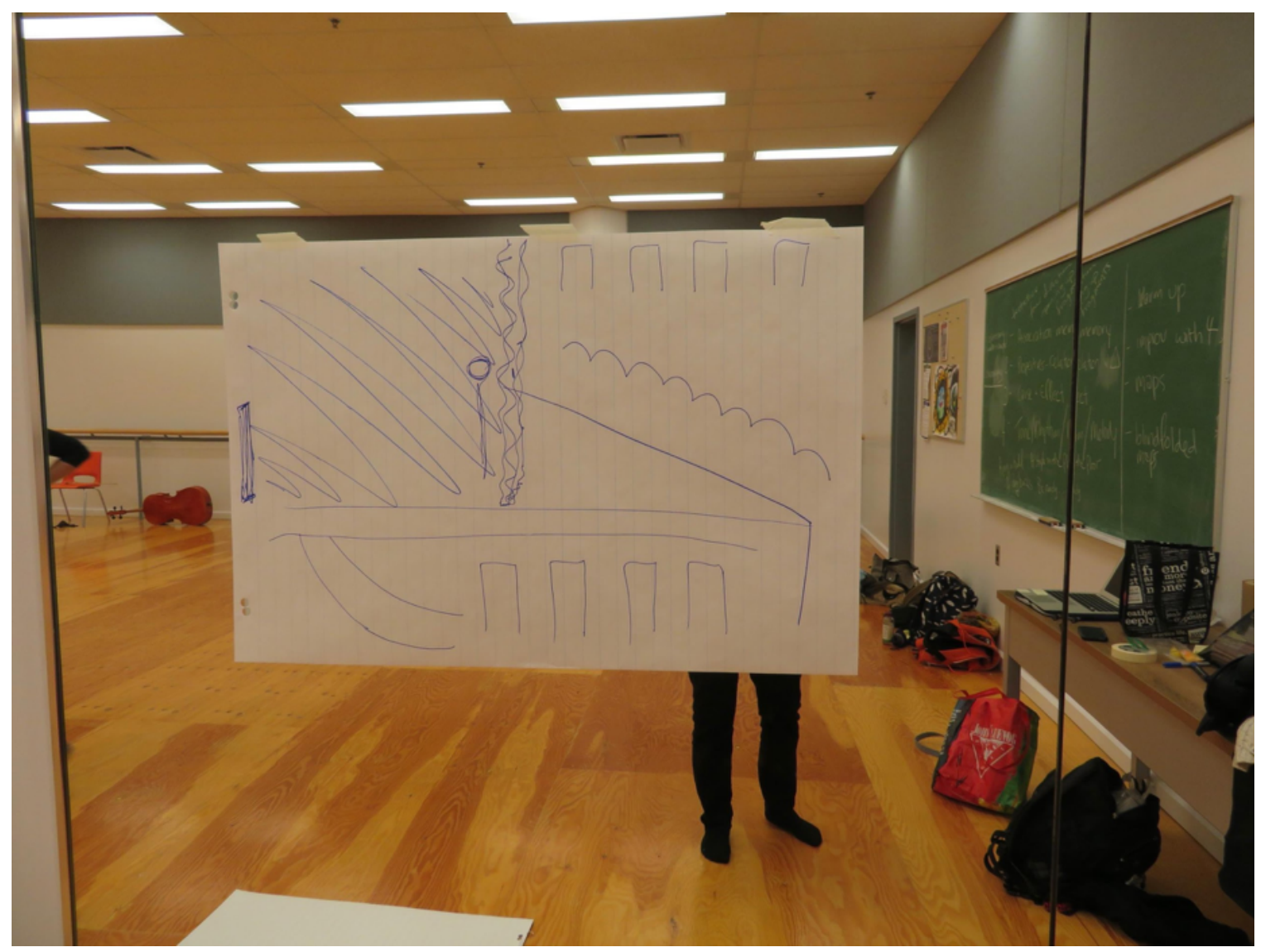

Figure 1 carto-elicitation

\section{About the Author}

Terry Sefton is Associate Professor at the University of Windsor, where she teaches music and arts pedagogy in the Bachelor of Education program; and qualitative and arts-based research theory and methodology in the graduate programs. Dr. Sefton has performed as a chamber musician in Canada, the US, Britain, and France, and has worked with contemporary composers, commissioning and performing new compositions at a number of venues including Concerts de Musique Contemporaine in Montréal, the Music Gallery in Toronto, Aeolian Hall and Museum London in London, Ontario. In 2017, she exhibited video and performance work in the Art Gallery of Windsor Triennial of

Sefton, Terry. 2018. Teaching for creativity and informal learning in liminal spaces. Action, Criticism, and Theory for Music Education 17 (3): 79-100. doi:10.22176/act17.3.78 
Contemporary Art. In addition to her performance-based creative work, Dr. Sefton has published in academic journals and books. Her research interests include institutional ethnography, identity of the artist, the arts in higher education, music education, and sociology of the arts.

\section{References}

Baillie, Caroline, John A. Bowden and Jan H.F. Meyer. 2013. Threshold capabilities: Threshold concepts and knowledge capability linked through variation theory. The International Journal of Higher Education and Educational Planning 65 (2): 227-46.

Barthes, Roland. 1975. The pleasure of the text. New York: Hill and Wang.

Becker, Howard. 1982. Art worlds. Berkeley, CA: University of California Press.

Bennett, Dawn, David Wright, and Diana Blom. 2009. Artist academics: Performing the Australian research agenda. International Journal of Education \& the Arts 10 (17).

Bourdieu, Pierre. 1994. The field of cultural production. Cambridge, UK: Polity Press.

Broadhurst, Susan. 1999. Liminal acts: A critical overview of contemporary performance and theory. London: Cassell.

Cook-Sather, Alison, and Zanny Alter. 2011. What is and what can be: How a liminal position can change learning and teaching in higher education. Anthropology \& Education Quarterly 42 (1): 37-53.

Côté, James, and Anton Allahar. 2011. Lowering higher education: The rise of corporate universities and the fall of liberal education. Toronto, ON: University of Toronto Press.

Csikszentmihalyi, Mihalyi. 1996. Creativity: Flow and the psychology of discovery and invention. New York: Harper Collins.

Elkins, James. 2001. Why art cannot be taught. Chicago, ILL: University of Illinois Press.

Finn, Patrick. 2015. Critical condition: Replacing critical thinking with creativity. Waterloo, ON: Wilfrid Laurier University Press.

Fullan, Michael. 2013. Great to excellent: Launching the next stage of Ontario's education agenda. Retrieved from: http://www.michaelfullan.ca

Sefton, Terry. 2018. Teaching for creativity and informal learning in liminal spaces. Action, Criticism, and Theory for Music Education 17 (3): 79-100. doi:10.22176/act17.3.78 
Gallagher, Kathleen. 2000. Drama education in the lives of girls: Imagining possibilities. Toronto, CA: University of Toronto Press.

Geertz, Clifford. 1973 Thick description: Toward an interpretive theory of culture. in the interpretations of cultures; selected essays. New York: Basic Books.

Green, Lucy. 2005. The music curriculum as lived experience: Children's "natural" music-learning processes. Music Educators Journal 91 (4): 27-32.

Green, Lucy. 2009. Response to special issue of 'Action, criticism and theory for music education' concerning 'Music, informal learning and the school: A new classroom pedagogy'. Action, Criticism, and Theory for Music Education 8 (2): 120-132. http://act.maydaygroup.org/articles/Green8_2.pdf

Hamel, Jacques. 1997. Sociology, common sense and qualitative methodology: the position of Pierre Bourdieu and Alain Touraine. Canadian Journal of Sociology 22 (1): 95-112.

Heap, James. 2013. Ontario's quality assurance framework: A critical response. Interchange, 44 (3-4): 203-218.

Jones, Ken. 2016. Education in Britain: 1944 to the present. Cambridge, UK: Polity Press.

Kanellopoulos, Panagiotis. 2012. Envisioning autonomy through improvising and composing: Castoriadis visiting creative music education practice. Educational Philosophy and Theory 44 (2): 151-82.

Kutnowski, Martin. 2015. Peeking under the rug: Build a "candid" teaching portfolio." Hybrid Pedagogy, September 10, 2015, accessed at http://hybridpedagogy.org/candid-teaching-portfolio/

Newman, Henry. 1996/1852. The idea of the university. New Haven and London: Yale University Press.

Pesch, Udo. 2015. Tracing discursive space: Agency and change in sustainability transitions. Technological Forecasting \& Social Change, 90(Part B), 379388.

Sefton, Terry, and Jonathan G. Bayley. 2013. The performing professor: Conflicts of identity and work in faculties of education. In Personhood and musical learning: Connecting perspectives and narrative/s, edited by Susan O'Neill, 319-37. Toronto, ON: Canadian Music Educators" Association.

Sefton, Terry. 2018. Teaching for creativity and informal learning in liminal spaces. Action, Criticism, and Theory for Music Education 17 (3): 79-100. doi:10.22176/act17.3.78 
Sefton, Terry, and Kathryn Ricketts. 2018. Stories of Windsor: Sites of fascination and performances of place. In Downtown's-Urban Renewals Today for Tomorrow: The 2017 Windsor-Essex Triennial of Contemporary Art. Catalogue. Windsor, ON: Art Gallery of Windsor.

Smith, Dorothy. 1999. Writing the social: Critique, theory, and investigations. Toronto: University of Toronto Press.

Söderbäck, Fanny. 2017. Liminal spaces: Reflections on the inbetween. Architecture and Culture 5 (3): 383-93.

Sullivan, Grahame. 2006. Research acts in art practice. Studies in Art Education: A Journal of Issues and Research 48 (1): 19-35.

Taylor, Charles. 2004. Modern social imaginaries. Durham, NC: Duke University Press.

Willey, Robin. 2016. Liminal practice: Pierre Bourdieu, madness, and religion. Social Compass 63 (1): 125-41.

Wright, Ruth. 2010. Informal music learning, improvisation and teacher education. British Journal of Music Education 27 (1): 71-87.

Wright, Ruth. 2014. The fourth sociology and music education: Towards a sociology of integration. Action, Criticism, and Theory for Music Education 13 (1): 12-39. 